\title{
doi.org/10.46291/ISPECIJSSHvol4iss2pp1-27
}

\section{Teknostres ile Değişime Direnç Arasındaki İlişki: Havacılık Sektöründe Bir Araştırma}

Mustafa ALTINTAŞ

\author{
Öğr. Gör., Bozkurt MYO - Sivil Hava Ulaştırma İşletmeciliği, Pamukkale Üniversitesi, \\ Denizli / Türkiye, maltintas@pau.edu.tr
}

\begin{abstract}
Özet
Her geçen gün daha da önemli hale gelen teknoloji, örgütlerdeki iş tanımlarını, iş yapış tarzlarını ve örgütlerin üyelerinden beklentilerini farklı bir boyuta taşımaktadır. $\mathrm{Bu}$ gelişim sürecinde işletmeler örgütsel yapılanmalarını farklılaşan iş yaşamı şartlarına uygun düzenleyerek, son teknolojiye uyumlu uygulama ve araçları iş yapış süreçlerine dâhil ederek oluşturmalıdır. Teknolojik gelişmelerin örgüt yapılanmalarında meydana getirdiği değişimlere çalışanların uyum sağlaması ve bu değişimleri içselleştirmesi son derece önemli olduğu gibi, çalışanlarında bu değişime ayak uydurabilmesi de oldukça önemli bir hal almaktadır. Örgüt yapılarının ve iş yapış biçimlerinin hızlı bir şekilde değişmesi, bilgi eksikliği, yetersizlik hissi, belirsizlik veya aşırı bilgi yüklenmesi gibi nedenlerle çalışanlar üzerinde aşırı kaygı ve stres yaratabilir. Oluşan bu stres ve kaygı çalışanlar üzerinde değişime direnç konusunu gündeme getirmektedir. Değişimin çalışanlar üzerinde yaratacağı ekonomik, sosyolojik, psikolojik ve rasyonel nedenlerle oluşan olumsuz etkiler bireylerde bilişsel, davranışsal ve duygusal tepkilere neden olabilmektedir. Teknolojik gelişmeler doğrultusunda çalışanlar üzerinde oluşan stresin, çalışanların değişime karşı direnç göstermesi ile bir ilişkisi olabileceği düşünülmektedir. $\mathrm{Bu}$ doğrultuda çalışmanın amacı; teknostres ve değişime direnç arasındaki ilişkiyi araştırmaktır. Araştırma kapsamında; Teknostres ölçeği olarak Tarafdar vd. (2007) tarafından geliştirilen ve Türen vd. (2015) tarafından düzenlenen Teknostres ölçeği kullanılmıştır. Örgütsel değişime direnç ölçeği olarak Oreg (2006) tarafından geliştirilen ve kullanılan üç boyutlu değişime direnç ölçeği kullanılmıştır.
\end{abstract}

Anahtar Kelimeler: Teknostres, Stres, Değişime Direnç, Sivil Havacılık

\section{The Relationship Between Technostress and Resistance to Change: A Research in the Aviation Sector}

\begin{abstract}
Technology, which is becoming more and more important every day, brings the job descriptions, the way of doing business and the expectations of the members of the organizations to a different dimension. In this development process, businesses should organize their organizational structures in accordance with different business conditions and include the latest technology compatible applications and tools in their business processes. It is extremely important for the employees to adapt and internalize these changes in the organizational structures, as well as to keep up with these changes in their employees. Rapid changes in organizational structures and ways of doing business can create extreme anxiety and stress on employees due to lack of information, feeling of inadequacy, uncertainty, or overloading of information. This stress and anxiety raises the issue of resistance to change on employees. Negative effects caused by economic, sociological, psychological and rational reasons that change will create on employees can cause cognitive, behavioral and emotional reactions in individuals. In line with the technological developments, it is thought that the stress on the employees may be related to the resistance of the employees to change. The purpose of the study in this direction; to investigate the relationship between technology and resistance to change. In the scope of the
\end{abstract}

Year 4/ 2020, Volume-4, Issue-2 | WwW.ispecjournal.org 
research; As technostress scale by Tarafdar (2007) and by Türen (2015), the technostress scale was used. The three-dimensional change-resistance scale developed by Oreg (2006) was used as the scale of resistance to organizational change.

Keywords: Technostress, Stress, Resistance to Change, Civil Aviation

\section{Giriş}

Stres kavramı ilk kez Hans Selye tarafından ortaya atılmış ve bireyin maruz kaldığı her türlü değişikliğe karşı gösterdiği tepki olarak tanımlamıştır (Selye, 1997) Stres, en genel anlamıyla, dış çevre koşulları ile bireyin kendi düşünce, tutum, yetenek, beceri ve değerleri arasındaki uyumsuzluktan kaynaklanan bir gerilim durumudur (Tınar, 1996). Birçok araştırmacı stresi: Kişinin ve kişinin etrafındakileri çeşitli yollarla etkilediğini ve bu süreçte insanların dışarıdan gelen uyarıcıları bir tehdit gibi gördüğü, hoş olmayan durum olarak tanımlamaktadır (Abramson, Metalsky ve Alloy, 1989; Dağ, 1990; Steers, 1981).

Stresin bireyde kalp atış hızının artması, kan basıncı seviyesinin yükselmesi ve kas gerginliği gibi çeşitli fiziksel semptomlar yaratabileceği belgelenmiştir (Jena, 2015). Stres, o an ki durumun gerçekte ne olduğu ile ilgili değil, bireyin o olay karşısında nasıl etkilendiğine bağlı olarak ortaya çıkan bir kaygı ve endişe durumdur. Oluşan durum tek başına strese neden olan unsur değildir. Burada dikkat edilmesi gereken, gerçekleşen durum ile o olaydan etkilenen kişi arasındaki etkileşimdir (Cartwright ve Cooper, 1997).

Lazarus, stres yaşayan bir bireyin bu süreçte iki tip değerlendirmede bulunduğunu söylemektedir. Birincisi aşamada bireyin içinde yer aldığg çevreyi tehditkâr, zarar verici veya riskli olarak değerlendirdiğini, ikincisinde ise, ilk değerlendirmede karşılaştığı zorluklarla baş edebilmek için ihtiyacı olduğu kaynakları değerlendirmektedir. Bireyin özellikle ikinci aşamadaki değerlendirmesinde sahip olduğu kaynakların birinci değerlemesindekine göre vereceği tepkiler için yeterli olmayacağını düşündüğü zaman kaygı, endişe, kan basıncının yükselmesi, terleme, öfke, üzüntü, kıskançlık gibi hissiyatlar ile karşı koymaya çalışmaktadır (Lazarus, 1966).

Bireyin yaşamında stres oluşturabilecek çok sayıda faktör vardır. Bunlardan birisi iş yaşamında yaşanan, çeşitli nedenlerden doğan ve birey üzerinde negatif bir etki oluşturan faktörlerdir (Wolever vd., 2012). Çeşitli nedenlerden kaynaklanabilecek olan iş yaşamındaki stres, işgörenin fiziksel veya ruhsal sağlığını, işin verimliliğini, çalışanlar arasındaki iletişimi, 
örgütsel etkinliği ve işe odaklanmayı olumsuz yönde etkileyebilecek bazı sonuçlar doğurmaktadır (Abramson, Metalsky ve Alloy, 1989; Dağ, 1990; Steers, 1981).

Stresin çalışma yaşamındaki etkileri, bireysel farklılar da göz önüne alındığında, fizyolojik, psikolojik veya davranışsal değişimlere neden olarak ciddi sıkıntılara yol açmakta ve bireyleri olumsuz etkilenmektedir (Pehlivan, 1995). Çalışma yaşamındaki stres kaynakları çok çeşitli nedenlerden doğabildiği gibi, zaman zaman bu durum teknolojik gelişmeler sonucu oluşan, sürekli öğrenme ve gelişme gerektiren durumların birey üzerinde yarattığı endişe ve yetersizlik hissinden doğabilir (Ragu - Nathan vd., 2008).

\subsection{Teknostres}

Technostress" terimi, ilk Craig Brod'da (1984) ortaya çıkmış olup, kullanıcının yeni teknoloji ile yeterince baş edememesi nedeniyle, sağlıklı düşünememesi sonucunda ortaya çıkan modern bir uyum hastalığı olarak tanımlanmıştır (Wang, Shu ve Tu, 2008).

Weil ve Rosen (1997) teknostrese çalışan üzerinde olumsuz bir psikolojik, davranışsal ve fizyolojik etki olarak bakarken, Arnetz ve Wiholm (1997) ise, teknolojik gelişmelerin yapılan işi doğrudan etkilediği durumlarda, bazı çalışanlarda gözlenen fizyolojik uyarılma ve zihinsel durum olarak ele almaktadır. Hudiburg (1989), Teknostresin yeni teknolojik cihazların kullanımında yaşanan uyum problemlerinin neden olduğu modern hastalığın bir parçası olduğunu söylemiştir. Teknostresin oluşum sürecinin, bireylerin örgütlerdeki var olan ya da değişen iletişim ve bilgi teknolojilerine yabancılaşması, bunun neticesinde hata yapmaktan korkar hale gelmesi ile kaygı, endişe, tedirgin olma gibi hislerle bilgisayar ve benzeri teknolojik araçlara karşı bir önyargı geliştirmesi olduğu söylenebilir.

Teknostresin ortaya çıkardığı belli başlı özelliklerinde değişen iletişim ve günden güne gelişen bilgi teknolojilerinden dolayı ciddi kaygı duyma, endişe, şüphe etme, sınırlı düzeyde özyeterlilik duygusunun meydana çıktığı söylenebilir (Salanova vd., 2013). Bireylerin maruz kaldığı teknostresin boyutunu örgütlerdeki hâlihazırdaki süreçlerin ne oranda bilgisayara bağımlı olduğu ve bireyin bu teknolojiyi kulanım becerileriyle alakalı olduğu vurgulanmaktadır. İnsanlar hızlı bir şekilde kendilerini çok başka işler ile ilişkili türlü türlü uygulamayı aynı anda kullanmak zorunda kalabilirler (Clark ve Kalin, 1996).

Gelişen teknoloji kullanıcılarına işlerini daha kısa sürede yapmalarını sağlamakla birlikte aynı zamanda onları birçok işi bir arada yapabilecek ortamı sunmaktadır (Weil ve Rosen, 1999). Year 4/ 2020, Volume-4, Issue-2 | WwW.ispecjournal.org 
Ancak bu durum her zaman olumlu sonuçlar doğurmayabilir. Çağımızla birlikte gelişen ve farklılaşan iş yapma biçimleri, insanların sahip olduğu bilgiler ve tecrübeler ile onlardan istenilen tarzda iş yapabilmelerini zorlaştırdığından, bu aşamada değişime uyum için gerekli bilgilendirme ve eğitimler sunulup, çeşitli değişim programları gündeme gelebilir (Türen vd., 2015).

$\mathrm{Bu}$ süreç iyi yönetilmezse, yaşanan durum sonucu oluşan aşırı bilgi yüklemesi, karmaşıklık ve belirsizlik birey üzerinde stres yaratabilir. Çalışma yaşamında kullanılmaya başlanan yeni teknolojinin, daha fazla endişe ve stresle sonuçlanacak olan iş güvensizliği hissine yol açacağ tahmin edilmektedir. Teknolojinin işyerindeki stres üzerindeki etkisi, "teknostres" olarak adlandırılan yeni bir stres tipine yol açmıştı (Brod, 1984).

Rosen ve Weil tarafindan yapılan bir araştırma, üç yıl boyunca, büro çalışanlarının, yöneticilerin ve yöneticilerin büyük çoğunluğunun (\% 80) teknolojinin yaşamlarına ilave stres getirdiğini bildirdi (Weil ve Rosen, 1999). Ampirik çalışmalar, teknostres seviyesinin, görevlerini yerine getirirken teknolojiyi kullanan çalışanlar arasında daha yüksek olduğunu ortaya koydu (Schuldt \& Totten, 2008; Agbu and Simeon, 2011; Walz, 2012). Teknolojik gelişmelerin ortaya çıkardığı değişimi yönetebilmek için örgütler çeşitli önlem planları yapsalar da çalışanların bu süreçteki değişimden çeşitli şekillerde etkilendikleri ve bu koşulların yarattığı belirsizlik, karmaşıklık ve aşırı bilgi yüklenmesi nedeniyle çalışanlar için olumsuz etkiler yaratabileceği düşünülmektedir. (Tarafdar vd., 2007). Bu durumun birey üzerinde yarattığı stres, teknolojilerdeki değişimden kaynaklandığından tekno-stres adıyla anılmaktadır (Alam, 2015). Bir diğer deyişle, Bireyin teknolojik değişiklikler nedeniyle oluşan endişe ve kaygı duyma, bunlarla beraber tedirgin hissederek, korku, öfke, gibi stres altında tepkiler vermesine teknostres adı verilmektedir (Weil ve Rosen, 1997)

\subsubsection{Teknostresin Boyutları}

Teknostres ilk olarak Tarafdar vd. (2007); teknolojik yüklenme, teknolojik istila, teknolojik karmaşıklık, teknolojik güvensizlik ve teknolojik belirsizlik olmak üzere beş boyutta ele almıştır. Daha sonra Türen vd. (2015) tarafından bu beş boyut azaltılmış ve teknolojik yüklenme, teknolojik karmaşıklık ve teknolojik belirsizlikten meydana gelen 3 boyut belirlenmiştir. 


\subsubsection{Teknolojik Yüklenme}

Rol yüklemesi, bir bireyin rolünün gereklilikleri zorluk seviyesi veya iş miktarı bakımından kapasitesini aştığında gerçekleşir (Tarafdar vd., 2007). Çalışanların kapasitesini arttırmak amacıyla kullanılan yeni teknoloji, aşırı bilgi akışı ve yüküne maruz kalmaları sonucunu oluşan durumu ifade etmektedir.

\subsubsection{Teknolojik Karmaşıklık}

Bireylerin iş yaşamının gereği olan yükümlülük ve sorumluluklarını kendisinden beklenildiği gibi yerine getirebilmek için kullanma mecburiyetinde kaldığı bilgi ve iletişim teknolojisini öğrenmede yetersiz kalması ve sorunlar yaşamasıdır (Yener, 2018) Bireylerin yaşadığı bu karmaşıklık işlerine karşı sinik davranışlar içerisinde olmalarına neden olarak çalışma performanslarına olumsuz yansıyabilmektedir.

\subsubsection{Teknolojik Belirsizlik}

Yüksek teknolojilerin yoğun olarak kullanıldığı örgütlerde yaşanan değişim özellikle ilk aşamalarda belirsizlik oluşturmaktadır. Bu durum çalışanlara yetersizlik ve yenilmişlik duygusu hissettirebilmekte bazı durumlarda ise yeni çıkan teknolojileri öğrenip kullanma konusunda çaresizlik hissi hissettirebilmektedir (Türen vd., 2015).

\section{Değişime Direnç}

Değişimin olduğu her ortamda değişime yönelik bir direncin de meydana gelme ihtimali vardır. Literatürde "değişim” yaklaşımını ilk defa araştıran araştırmacılardan olan Lewin (1947), değişim kavramını, direnç ifadesi ile yan yana kullanmaya başlamış ve sonraki çalışmalarda "değişim” ve "direnç" kavramı birlikte kullanılmaya başlanmıştır. Lewin, açık bir direnç tanımı yapmamış, değişimi destekleyen kavramın “arzu”, karşı çıkma kavramını ise "direnç" ifade etmiştir.

Değişim; bir şeyi herhangi bir durumdan başka bir duruma ya da düzeye getirmeyi ifade eder. Örgütlere baktığımızda ise bu durum kişilerin veya nesnelerin yerlerinin değiştirilmesi, yeni teknolojilerin öncekilerin yerlerini alması veyahut bireysel bilgi ve becerilerin olduğundan başka bir seviyeye geçiş yapması olarak ifade edilebilir (Taşlıyan ve Karayılan, 2011). Başka bir ifadeye göre değişim; önceden planlanmış veyahut planlanmamış şekilde herhangi bir sistemin, sürecin ya da daha önce var olan bir düzenin belirli bir düzeyden farklı düzeye Year 4/ 2020, Volume-4, Issue-2 | wWw.ispecjournal.org 
geçirilmesidir (Sabuncuoğlu, 2008). Direnme ise; bireyin kendi çıkarlarını düşünerek, kendisini değişimin etkisinden korumaya çalışması, tepki göstermesidir. (Özgen ve Ölçer, 1997).

Bir organizasyonda görev yapan çalışanlar genellikle, gizli veya açık bir şekilde değişimi sabote etme eğilimi gösterirler (Sabuncuoğlu, 2000). Değişimin, onların alışkanlıklarını da değiştireceğine inanırlar. Bu yüzden çalışanlar değişime karşı soğuk davranırlar. Bu durum gizli direnç mevzu bahis olduğunda ise daha tehlikeli bir hal alır. Değişim uzmanı çalışanlardaki bu gizli direnci yeterince algılayamaz ve analiz edemezse değişim süreci başarısızlıkla sonuçlanabilir. Başarılı olmak için organizasyondaki çalışanların hepsiyle işbirliği yapmak gerekir (Porras ve Robertson, 1992; Schyns, 2004). Başarısızlıkta ise memnuniyetsizlik, verimliliğin ve performansın düşmesi, devamsızlığın giderek artması, işten ayrılmaların yaşanması gibi sonuçlar ortaya çıkabilir (Miller vd., 1994; Stanley vd., 2005).

Değişim örgütten örgüte farklılık da gösterebilir. Kimi örgütlerde olumlu sonuçlar verdiği gibi kimi örgütlerde olumsuz sonuçlar da verebilir. Olumlu olarak örgütün gelişmesini, yöntem ve süreçlerde daha etkili ve verimli olmasını sağlayabilir. Olumsuz olarak ise; örgütün etkinliğini ve verimliliğini düşürerek, örgütsel amaçlardan sapmasına yol açabilir.

\subsection{Değişime Direncin Nedenleri}

Hiçbir insan sahip olduğu alışkanlıklarını kolay kolay bırakamaz ya da bırakmak istemez. Hali hazırda var olan düzenlerinin ve şartlarının değişime uğraması insanlara rahatsızlık verebilir. Diğer taraftan değişim yeni kural ve kaideler doğuracağından dolayı bu kurallara uyma mecburiyetinde kalan bireylerde farklı türlerde stres ve direnme özellikleri taşıyan davranışlar ortaya çıkabilir (Stoner ve Wankel, 1986).

Bireylerin değişim konusunda direnme nedenlerini; ekonomik, sosyolojik, psikolojik ve rasyonel nedenler olarak dört başlık altında toplamak mümkündür. Ancak bu nedenleri kesin çizgilerle birbirlerinden net olarak ayırmak da tam doğru olmayacaktır. Çünkü aralarında çok ince bir çizgi olan bu nedenlere bakıldığında, ekonomik bir neden bazen hem sosyal bir nedenle ilişkili olabildiği gibi hem de rasyonel ve psikolojik nedenlerle de ilişkili olabilir. Bu diğer nedenler için de geçerli bir durumdur. 


\subsubsection{Ekonomik Nedenler}

Bir organizasyonda çalışanlar için en büyük korkulardan birisi teknolojik gelişmeler olabilmektedir. (Mullins, 1993). Çalışanlar teknolojik gelişmelere yetişememe korkusu ve değişen teknolojik bilgi ve süreçler sebebiyle elindeki işinden olacağını düşünerek direnç gösterme eğiliminde bulunurlar (Oreg, 2006). Bunun sebebi ise çalışanların daha önceden edinmiş oldukları bilgi, beceri ve alışkanlıkların kaybedilmesi, değişimin getirdiği teknolojinin kullanılması için sahip olunması gereken yeni tekniklerin öğrenilmesi onları zorlayabilir. Aslında uzun vadede, çalışanların kendi ekonomisi için belki de bu değişim daha yararlı olacak ve onlara yeni iş kapıları açacaktır. Fakat çalışanlar ya buna inanmazlar ya da inanmak istemezler. Çalışanın o anki sahip olduğu statüsünün, ustalığının ve sahip olduğu ekonomik ferahlığının yitirilme düşüncesi, yıllarca öğrendiklerinin yanı sıra, hiç bilmediği yeni teknolojiyi öğrenme çabasına girmek istememesi de değişime karşı direnmesine neden olabilir (Choi ve Ruona, 2011). Çalışan bir kişi, bir işin gerektirdiklerini öğrenebilmek için yıllarca zaman harcamıştır ve onun yapacağı işi makinenin yapması, çalışanın verdiği bütün emeklerin boşa gideceğini düşünmesine yol açar. Onun düşündüğü ve onun için mühim olan şey kendi yaşam şartları ve ailesinin şuandaki refah düzeyidir. Çalışan için önemli olan kendi çıkarlarıdır ve bu çakırları kaybedebileceği düşüncesi onu değişime direnç eğilimine sokabilir. Çıkarları ortadan kalkan veya azalan çalışan sayısı da ne kadar çok olursa, değişimin karşısındaki tepki ve direnç de o oranda yüksek ve sert olabilmektedir.

\subsubsection{Sosyolojik Nedenler}

Değişimin inşaların ya da onların yer aldıkları gruplardaki sosyal değerlerle çatışması söz konusu olduğunda, değişime karşı direnç gösteren davranışlar da ortaya çıkabilir. Eğer çalışanlar kariyerleri, statüleri, prestijleri, yetki ve sorumlulukları ile ilgili endişe duymaya başlarsa değişime karşı direnç de gösterirler (Eren, 2004). Öte yandan çalışanların içinde oldukları gruplara bağlılı̆̆ da direnmede pay sahibi olabilir. Eğer değişim gruptaki birlikteliği tehdit ediyorsa ve grupta da çalışanlar arasında iyi bir uyum ve birliktelik varsa, tüm grup üyeleri değişime karşı direnç gösterebilir. Çünkü sosyal bağların yeniden güçlendirilmesi ve inşa edilmesi gruplar için zor olabilmektedir (Durna, 2002). Ayrıca, eğer çalışanın içinde olduğu grup değişime karşı olumsuz bir davranış sergiliyorsa Çalışanın kendisi de gruba ayak uydurarak değişime tepki gösterebilir. Yani grubun tavrı da, çalışanlar üzerinde etkili olabilmekte, grup normlarına uygun davranmaya zorlayabilmektedir (Daft, 1999).

Year 4/ 2020, Volume-4, Issue-2 | www.ispecjournal.org 


\subsubsection{Psikolojik Nedenler}

Kaynaklarda değişim konusunda en ciddi direnç nedeninin psikolojik nedenlerden oluştuğu vurgulanmaktadır. Psikolojik direncin nedenleri ise; değişim ile beraber gelen yeni kaideler, denetlenme düzeyinin yükselmesine gösterilen tepki, yabancılaşma, kişisel düşmanlık, yeni düzendeki karmaşıklık ve bilgi yetersizliği, alışkanlıkların terkedilmesi, güven duygusunun azalması, artan ön yarg1, ilgisizlik, değişimin zarar vereceğinin düşünülmesi, yeni değişimden duyulan hayal kırıklığı olarak sayılabilir (Durna, 2002). Çalışanların davranışlarının temelinde önceden edindikleri alışkanlıklar yatar. Bundan dolayı alışıla gelmiş işleri yapmak çalışanları, psikolojik olarak rahatlatmakta ve güven vermektedir. Alışıla gelmiş bu alışkanlıkları değiştirmek çalışanlar için oldukça güç olabilir ve onların rutinlerini bozabilir; bu yüzden de değişime karşı direnç eğilimi gösterebilirler (Arslan, 2001).

\subsubsection{Rasyonel Nedenler}

Değişim çalışanların bireysel uzmanlıklarını zedeleyebilir ya da bir anda kullanılmaz bir hale sokabilir. Organizasyonlarda yapılan bir değişiklik ihtisas sahibi olmuş bir çalışanın yıllarca çabalayarak sahip olduğu uzmanlıklarını önemsiz duruma düşürebilir. İşin yeniden dizayn edilmesi ve yapılandırılmasıyla, çalışanın yıllarca yerine getirdiği yükümlülükleri ve sahip olduğu uzmanlığı başka bir çalışana geçebilir. Böyle durumlarda çalışanlarda değişime karşı direnç ortaya çıkabilir (Özkalp ve Kırel, 2010). Bu tip bir değişimde çalışanlar işlerini kaybetme endişesi duyar ve değişime karşı direnirler. Ayrıca çalışanlara değişime karşı uyum sağlayabilmeleri için zaman tanınmıyorsa o zaman da çalışanlar, değişimi yönetenlerin; kendilerine değer vermediklerini ve düşünmediklerini, sadece örgütün çıkarlarına değer verdiklerini ve önemsediklerini düşünerek değişime karşı direnç gösterebilirler.

Eğer değişimin çalışana maliyeti faydasından daha çoksa, değişime rasyonel bir direnç oluşabilir. Çalışanlar açısından her değişimde detaylı bir fayda maliyet analizi yapılması uygun olabilir; hem ekonomik yararı ve maliyeti göz önünde bulundurulmalı hem de sosyal/psikolojik fayda - maliyetler analizi yapılmalıdır (Daft, 1999). Örgütteki bireyler fayda maliyet analizi yaptıktan sonra değişime karşı nasıl bir tepki vereceklerine karar verirler. Hem ekonomik hem sosyal zararların tespiti göz önünde bulundurularak davranışlarını ve değişime karşı tepkilerini o doğrultuda şekillendirirler. 


\subsection{Değişime Direnç Boyutları}

Değişime direnç ile ilgili yapılan çalışmalar incelendiğinde, konuyla ilgili yapılan başlıca katkılardan birisinin Piderit' in (1999) yapmış olduğu çalışma kabul edilmektedir. Bu aşamaya kadarki çalışmalar (Maurer, 1996; Henry, 1997; Agocs, 1997; Waddell ve Sohal, 1998; Dent ve Goldberg, 1999) genellikle tek boyutlu çalışmalar olup, yalnızca yönetimin bakış açısıyla ele alınmış çalışmalardır (Stensaker ve Meyer, 2012). Piderit (2000) ise çalışanların bakış açısından değerlendirme yapılarak, değişimin daha iyi şekilde anlaşılabileceğini ve bu doğrultuda "duygusal, bilişsel ve davranışsal" boyutları kapsayan bir ' değişime direnç'” kavramının incelenmesi gerektiğini vurgulamaktadır.

\subsubsection{Bilişsel Direnç}

Davranışsal ve duygusal eğilimdeki direncin başlamadan önceki boyutu bilişsel direnç boyutudur. (Chung vd., 2012). Bilişsel faktör, davranışın harekete geçmeden önce düşünce veya inanç kısmı olarak ifade edilebilir. Bilişsel direnç, çalışanın yapılan ya da yapılması planlanan değişimin kendisi için ihtiyaç var mı, kendisine nasıl yarar sağlayacak, veyahut kuruma ne gibi faydaları olacak ya da zarar mı verecek gibi sorulara yanıt aradığı, çalışanın değişim hakkında ne düşündüğünü meydana çıkaran ilk evredir (Oreg, 2006). Diğer bir deyişle, bu boyutta çalışanların değişime ilişkin ne düşündüklerini sorguladıkları ilk evredir.

\subsubsection{Duygusal Direnç}

Değişime karşı direncin bu boyutunda, çalışanların değişim hakkında besledikleri duygu ve hisleri ele alınmaktadır. Duygusal faktör bir tutumun his ve duygularla ilgili kısmını oluşturmaktadır (Oreg, 2006). Çalışanların, öfkeli, kaygılı, heyecanlı, gergin vs. gibi duygularının yanı sıra değişimle ilgili olumlu veyahut olumsuz duyguları da duygusal dirence dahildir. Bunlar haricinde duygusal direnç, çalışanların değişim süreci ile ilgili yetersiz bilgilendirildiğinde veya iyi bir iletişimin oluşmamasında da meydana gelebilmektedir (Coetsee, 1999). Kısaca, bu boyutta da çalışanların değişime karşı ne hissettikleri sorgulanmaktadir.

\subsubsection{Davranışsal Direnç}

Davranışsal faktör çalışanların, değişime yönelik nasıl davrandığı ya da nasıl bir davranma niyeti taşıdığı ile ilgilidir. Davranışsal bileşen, işyerinde gerçekleşen değişim sürecine tepki

Year 4/ 2020, Volume-4, Issue-2 | www.ispecjournal.org 
olarak, değişimden memnuniyetsizlik duymak, şikâyetçi olmak, diğer çalışma arkadaşlarını da bu yönde inandırma gayreti içine girmek gibi davranış ve tutumlarını kapsar. Başka bir değişle, değişime karşı gösterilen direncin bu evresinde, örgütteki bireylerin çalıştıkları yerde değişim konusunda gösterdikleri hareketleri bu boyutta yer almaktadır (van Dam vd., 2008). Çalışanların gösterdiği bu hareket ve davranışlar da, değişime engel olmak, değişimi sabote etmek, çeşitli gösterilerde bulunmak şeklinde kendini gösterebilmektedir (Singh vd., 2012).

Değişime direncin bu üç boyutu, çalışanların bir duruma karşı davranış göstermesinin ü̧̈ farklı türde yansımasıdır. Daha önce de değinildiği gibi bu üç bileşenin birbirinden tamamen bağımsız olması düşünülemez. Çalışanların, bir değişim söz konusu olduğunda, hissettiği duygular çoğu zaman değişimin hakkında nasıl muhakeme ettikleriyle ve onunla ilgili bulunduğu davranışlarla uyum gösterecektir. Bunun yanı sıra, bu üç boyut her ne kadar diğerlerinden bağımsız olmasa da ayrıdır. Bu üç boyut da direncin başka bir tarafına dikkat çekmektedir. Boyutlardan biri, çalı̧̧anların herhangi bir değişim söz konusu olduğunda nasıl hissettiği üzerinde birincil etkiye sahip olabilirken, diğer bir boyut çalışanların davranışlarıyla ilişkili olabilmektedir. Yani, çalş̧anların bir değişim söz konusu olduğunda düşünceleri, duyguları ve davranışları farklı farklı sonuçlar doğurabilmektedir (Oreg, 2006).

\section{Araștırma}

\subsection{Araştırmanın Amacı ve Hipotezleri}

$\mathrm{Bu}$ araştırmanın amacı, teknostres ile değişime direnç arasındaki ilişkinin belirlenmesidir. $\mathrm{Bu}$ açıdan, "'teknostres ile değişime direnç arasında ne tür ve nasıl bir ilişki var?" araştırmanın temel sorusu olmuştur. Bu doğrultuda araştırmanın hipotezleri;

H1: Teknostres ile değişime direnç arasında istatistiki olarak anlamlı bir ilişki vardır.

H2: Teknostres ile değişime direncin alt boyutları arasında istatistiki olarak anlamlı bir ilişki vardir.

H3: Değişime direnç ile teknostresin alt boyutları arasında istatistiki olarak anlamlı bir ilişki vardir. 


\subsection{Araştırmanın Önemi}

Güncel ve dikkat çekici bir konu olmasına karşın teknostres ile değişime direnç arasındaki ilişki ülkemizde daha önce çalışılmamıştır. Dünyada ise oldukça az sayıda çalışmaya konu olduğundan dolayı çalışma konusuna ilişskin yayınlar sınırlı kalmıştır. Alanda yeterli sayılamayacak sayıda yayın olmasından dolayı yapılan bu çalışmanın önem arz edeceği düşünülmektedir. Bu bakımdan, teknostres ile değişime direnç arasındaki ilişkinin sonuçları detaylı olarak incelenerek alanla ilgili sonraki çalışmalara katkıda bulunması ve bir çerçeve oluşturması ümit edilmektedir.

\subsection{Araştırmanın Yöntemi}

Araştırmada verilerin elde edilmesi için anket formundan yararlanılmıştır. Araştırma için ilişkisel tarama modelinden faydalanılmıştır. Araştırmanın yapıldı̆̆ 1 havalimanı çalışanlarının sorulara vermiş oldukları cevaplar ve ulaşılan veriler araştırmalarda çok sık kullanılan SPSS programı vasıtasıyla analiz edilmiştir. Araştırmadan elde edilen verilerin analizlerin başlamadan evvel anket formunda bulunacak değişkenlerin aynı doğrultuda olması için ters sorulan soruların yeniden kodlama işlemi ile dönüştürülmesi sağlanmıştır. İlk olarak ankette yer alan demografik soruların frekans dağılımları gerçekleştirilmiştir. Daha sonra elde edilen verilerin normal dağılımdan gelip gelmediği test edilerek, geçerlilik ve güvenilirliği (Cronbach Alpha Katsayısı) uygulaması ve faktör analizleri ile test edilmiştir. Demografik özelliklerin etki düzeyleri İndependent $\mathrm{T}$ testi ve Anova testleriyle analiz edilmiştir. Son aşamada korelayon analizinden faydalanılarak çalışmanın hipotez testlerini sınamak amaçlanmıştır.

\subsection{Araştırmanın Evreni ve Örneklemi}

Bu araştırmanın evreni 1 Ocak 2020 tarihi itibariyle Denizli Çardak Havalimanı'nda hali hazırda çeşitli birimlerde çalışan toplam 116 DHMİ personelinden meydana gelmektedir. Araştırmanın evrenindeki tüm DHMİ personeline ulaşılmaya çalışılarak örneklem alınmamıştır. Bu amaçla ulaşılmaya çalışılan DHMİ personelinden geri dönüş alınan 90 anket formu değerlendirilmiştir. Anketlerin kurumdan toplanması sonucunda geri dönüş oranı $\% 77,5$ 'tir. 


\subsection{Veri Toplama Araçları}

$\mathrm{Bu}$ araştırmada verileri elde etme amacıyla yararlanılan araçlar, Tarafdar vd,. (2007) bilim insanlarının geliştirdiği ve Türen vd,. (2015) tarafından Türk kültürüne uygun olarak hazırlanan 14 ifadeden ve üç boyuttan oluşan Teknostres Ölçeği ile Oreg (2006)'nın hazırladığı ve geliştirdiği 15 ifadeden ve üç boyuttan oluşan değişime direnç ölçeği kullanılmıştır.

Araştırmada kullanılan tüm ölçekler 1'den 5'e doğru değerlendirmeye tabi tutularak 5'li likert ölçeğinden faydalanılmıştır. 1=kesinlikle katılmıyorum şeklinde olup, 5=tamamen katılıyoruma doğru (en olumsuzdan en olumluya) bir değerlendirme söz konusudur. Tüm elde edilen veri ve bulguların analizi SPSS programı vasıtasıyla gerçekleştirilmiştir.

\subsection{Bulgular}

\subsubsection{Demografik Özelliklere İliş̧kin Bulgular}

Araştırma kapsamındaki katılımcıların demografik özelliklerine ait bilgiler Tablo-1'de gösterilmiştir.

Tablo 1. Katılımcılara ait demografik özellikleri

\begin{tabular}{|c|c|c|c|}
\hline \multicolumn{2}{|c|}{ Demografik Değişkenler } & \multirow{2}{*}{$\begin{array}{c}\text { Frekanslar } \\
40\end{array}$} & \multirow{2}{*}{$\frac{\text { Yüzdesi (\%) }}{44,4}$} \\
\hline Yası & $21-30$ yas & & \\
\hline & $31-40$ yas & 36 & 40,0 \\
\hline & 41 ve üstü & 14 & 15,6 \\
\hline & Toplamı & 90 & 100,0 \\
\hline \multirow[t]{3}{*}{ Cinsiyeti } & Erkek & 78 & 86,7 \\
\hline & Kadın & 12 & 13,3 \\
\hline & Toplam & 90 & 100,0 \\
\hline \multirow[t]{3}{*}{ Medeni Durumu } & Evli & 66 & 73,3 \\
\hline & Bekar & 24 & 26,7 \\
\hline & Toplamı & 90 & 100,0 \\
\hline \multirow[t]{5}{*}{ Eğitim } & Lise & 3 & 3,3 \\
\hline & Önlisans & 13 & 14,4 \\
\hline & Fakulte & 70 & 77,8 \\
\hline & Lisansustu & 4 & 4,4 \\
\hline & Toplamı & 90 & 100,0 \\
\hline Kurumda & $0-15$ & 68 & 75,6 \\
\hline Çalışma Yılı & $16-30$ & 22 & 24,4 \\
\hline
\end{tabular}




\begin{tabular}{llrc}
\hline & Toplamı & 90 & 100,0 \\
\hline Meslekte & $0-20$ & 79 & 87,8 \\
Çalışma Yılı & $21-40$ & 11 & 12,2 \\
& Toplamı & 90 & 100,0 \\
\hline Kurumdaki & Orta Düzey Y. & 6 & 6,7 \\
Pozisyonu & Alt Düzey Y. & 8 & 8,9 \\
& Çalışan & 76 & 84,4 \\
& Toplamı & 90 & 100,0 \\
\hline
\end{tabular}

Araştırmaya katılan çalışanların demografik dağılımları incelendiğinde; \%44,4'ü 21-30 yaş, \%40'1 31-40 yaş, \%15,6's1 ise 41 yaş ve üzerinde, çalışanların \%86,7'sinin erkek, \%13,3'ünün kadın çalışanlardan oluştuğu, ayrıca katılımcıların \%73,3'ünün evli, \%26,7'sinin bekar çalışan olduğu, katılımcılardan \%3,3'ü lise mezunu, \%14,4'ü önlisans mezunu, \%77,8'inin fakülte mezunu, \%4,4'ünün ise lisansüstü mezunu olduğu anlaşılmaktadır.

Katılımcıların kurumda çalışma süreleri incelendiğinde; \%75,6'sı 0-15 yı1, \%24,4'ü 16-30 yı1, katılımcıların meslekte çalışma sürelerine bakıldığında ise \%87,8'i 0-20 yı1, \%21,2'si 2140 yıl olarak belirlenmiştir. Son olarak katılımcıların \%6,7'si orta düzey yönetici, \%8,9'u alt düzey yönetici (en az bir astı var), \%84,4'ü ise çalışan statüsündedir.

Tablo 2. Normal Dağılıma Uygunluk Testi

\begin{tabular}{lccccccc}
\hline & İstatistik & Sd & P & Çarpıklık & Basıklık & Ort. & Medyan \\
\hline Teknostres & 0,146 & 90 & 0,008 & $-0,624$ & 0,256 & 2,13 & 2,19 \\
\hline Değişime Direnç & 0,128 & 90 & 0,021 & $-0,390$ & $-0,445$ & 1,97 & 2,06 \\
\hline
\end{tabular}

Yapılan normal dağılımız analizi sonucunda teknostres ve değişime direnç ölçeklerinin normal dağılımdan gelmediği tespit edilmiştir. Buna karşın normal dağılımdaki diğer varsayımlardan ortalama ve medyan değerlerinin uzak olmaması, çarpıklık ve basıklık değerlerinin (+/-) 1 değeri arasında olması ayrıca, örneklem hacminin de merkezi limit teoremi doğrultusunda 30'un üstünde olmasından dolayı verilerin normal dağllıma yakın bir dağılım gösterdiği neticesi elde edilmiştir (Büyüköztürk, vd. 2009).

\subsection{2. Ölçeğin Güvenirlik ve Geçerliliğine İlişkin Bulgular}

Katılımcıların örgütsel sağlık ölçeğindeki sorulara verdikleri cevapların tutarlılığını ölçmek amacıyla güvenilirlik analizi yapılmıştır. Güvenilirlik katsayısının 0,70 ve üzeri bir puanda çıkması anket puanlarının geçerliliği için yeterli görülmektedir (Büyüköztürk vd., 2003: 165).

Year 4/ 2020, Volume-4, Issue-2 | WWW.ispecjournal.org 
Tablo 3. Ölçeklerin Güvenirliği

\begin{tabular}{lcc}
\hline Ölçekler & n & Cronbach's Alpha $(\boldsymbol{\alpha})$ \\
\hline Teknostres & 14 & 0,799 \\
\hline Değişime Direnç & 15 & 0,892 \\
\hline
\end{tabular}

Tablo 3'den hareketle, kullanılan teknostres ölçeğinin güvenirliliğini ortaya koyan "Cronbach's alpha" $\alpha=0,799$ ve değiş̧ime direnç ölçeğinin güvenirliliğini ifade eden "Cronbach's alpha" $\alpha=0,892$ değerinde olduğu saptanmıştır. Sonuç olarak ölçeğin güvenirliğinin yüksek olduğunu söylemek mümkündür.

Yararlanılan ölçeklerin içerik geçerliliği alanında uzman kişiler tarafından değerlendirilmiş, yapı geçerliliği ise SPSS programındaki faktör analizi vasıtasıyla test edilmiştir. Bunun sonucunda ulaşılan bulguların faktör çözümlemesinde KMO ve Barlett analizleri yapılmıştır. KMO değeri (0.5)'ten büyük çıkmalı, Barlet analiz sonucu da anlamlı olmalıdır. KMO ve Barlett analizi neticelerinin faktör analizini gerçekleştirmeye olanak sağlamasıyla, ölçeğin asıl boyutlarını saptamak için Pattern Faktör analizi gerçekleştirilmiştir. Kaç adet faktörün ölçeği meydana getirdiğinin saptanmasında ise, özdeğeri ifade eden (Eigen value) istatistiği kullanılmış, sayısal olarak 1'den büyük faktörler anlamlı, küçük olanlar ise değerlendirmeye alınmamaktadır (Kalaycı vd., 2006). Öte yandan, faktörün belirlediği ifadeyi ölçmesi amacıyla o faktörle olan ilişkisini ifade eden faktör yükleri 0.40 ve üstünde bir değer alması önerilmektedir (Büyüköztürk, 2004). Tablo -4 ve Tablo -5 'te faktör analizine ilişkin bulgular yer almaktadır. 
Tablo 4. Teknostres Faktör Analizi

\begin{tabular}{llc}
\hline \multicolumn{1}{c}{ KMO Degeri } & & 0,769 \\
\hline \multirow{3}{*}{ Küresellik Testi } & Ki-kare Değeri & 603,195 \\
\cline { 2 - 3 } & $\mathrm{Df}$ & 78 \\
\hline Toplam Varyans & $\mathrm{p}$ & 0,000 \\
\hline
\end{tabular}

Teknostres Ölçeği

Faktör Yükleri

\begin{tabular}{|c|c|c|c|}
\hline & $\begin{array}{l}\text { Tekno } \\
\text { Yüklenme }\end{array}$ & $\begin{array}{c}\text { Tekno } \\
\text { Belirsizlik }\end{array}$ & $\begin{array}{c}\text { Tekno } \\
\text { Karmaşıklık }\end{array}$ \\
\hline $\begin{array}{l}\text { 1.Kurumumun sahip olduğu teknolojinin, bana daha çok iş } \\
\text { yapmayı zorlaması bende stres oluşturuyor }\end{array}$ & 0,864 & & \\
\hline $\begin{array}{l}\text { 2.Kurumumun sahip olduğu teknolojinin, beni oldukça } \\
\text { yoğun zaman çizelgelerine zorlaması bende stres oluşturuyor }\end{array}$ & 0,856 & & \\
\hline $\begin{array}{l}\text { 3.Kurumumun sahip olduğu teknolojiye uyum sağlayabilmek } \\
\text { için çalışma şeklimi değiştirmek bende stres oluşturuyor }\end{array}$ & 0,849 & & \\
\hline $\begin{array}{l}\text { 4.Kurumumun sahip olduğu teknolojinin, beni daha çabuk } \\
\text { bir şekilde iş yapmaya yöneltmesi bende stres oluşturuyor }\end{array}$ & 0,806 & & \\
\hline $\begin{array}{l}\text { 5.Kurumumdaki iş yüküm oldukça yoğun olduğundan dolayı } \\
\text { kullandığım teknoloji git gide karmaşıklaşıyor }\end{array}$ & 0,804 & & \\
\hline $\begin{array}{l}\text { 6.Kurumumdaki teknolojik araç gereçlerin yazılımları } \\
\text { düzenli aralıklarla değiştiriliyor }\end{array}$ & & 0,900 & \\
\hline $\begin{array}{l}\begin{array}{l}\text { 7.Kurumumdaki teknolojik } \\
\text { güncellemeler yap1liyor }\end{array} \\
\text { araç }\end{array}$ & & 0,861 & \\
\hline $\begin{array}{l}\text { 8.Kurumumdaki teknolojik araç gereçlerin donanımları } \\
\text { düzenli aralıklarla değiştiriliyor }\end{array}$ & & 0,768 & \\
\hline 9.Kurumumda devamlı güncel teknolojileri kullanıyoruz & & 0,477 & \\
\hline $\begin{array}{l}\text { 11.Kurumumda teknolojik bilgi düzeyimi yenilemek için } \\
\text { gerekli vakti şimdiye kadar yakalayamadım }\end{array}$ & & & 0,702 \\
\hline $\begin{array}{l}\text { 12.Kurumumun sahip olduğu teknolojiyi anlamayı genellikle } \\
\text { çok karmaşık bulurum }\end{array}$ & & & 0,850 \\
\hline $\begin{array}{l}\text { 13.Kurumumdaki görevimi tam anlamıla icra edebilmek } \\
\text { için kullandığım teknoloji hakkında yeterli bilgim yok }\end{array}$ & & & 0,831 \\
\hline $\begin{array}{l}\text { 14.Kurumumda kullandığım teknoloji hakkında iş } \\
\text { arkadaşlarım benden daha bilgilidir }\end{array}$ & & 0,405 & $-0,588$ \\
\hline
\end{tabular}

Tablo - 4'te ortaya çıkan faktör analizi neticesinde 10. madde diğer boyutun içine girdiği için analizden çıkarılmış ve yeniden analiz yapılmış ve “Teknostres Ölçeği”nin KMO değerinin 0,769 olduğu saptanmıştır. "Teknostres Ölçeği”"nin Barlett değerinin ( $p=0,000 / \chi 2=603,195$; p<0,01) anlamlı olduğu saptanmıştır. Analizde faktör sayısı belirlenirken özdeğerin, 1'in üzerinde bulunmasına ve faktör yüklerinin de 0,40 ve daha fazla bir değerde bulunması göz 
önünde bulundurulmuştur. Son olarak elde edilen yapı toplam varyansın \% 67,526'ini açıkladığı görülmüştür.

Tablo 5. Değişime Direnç Faktör Analizi
KMO Değeri
0,840

Küresellik Testi

\begin{tabular}{lc} 
Ki-kare Değeri & 786,579 \\
\hline Df & 105 \\
\hline p & 0,000 \\
\hline
\end{tabular}

Toplam Varyans

Faktör Yükleri

\section{Değişime Direnç Ölçeği}

\begin{tabular}{|c|c|c|c|}
\hline & $\begin{array}{l}\text { Davranışsal } \\
\text { Direnç }\end{array}$ & $\begin{array}{l}\text { Duygusal } \\
\text { Direnç }\end{array}$ & $\begin{array}{l}\text { Bilişsel } \\
\text { Direnç }\end{array}$ \\
\hline $\begin{array}{l}\text { 1. Değişimin kurumda iş yapma süreçlerini olumsuz } \\
\text { etkileyeceğine inaniyorum }\end{array}$ & $-0,689$ & & \\
\hline 2. Değişimin olumsuz etki yarattığına inanıyorum & $-0,880$ & & \\
\hline 3. Değişimin işime zarar vereceğini düşünüyorum & $-0,826$ & & \\
\hline 4. Değişimin kuruma fayda vereceğini düşünüyorum* & $-0,722$ & & \\
\hline 5. Değişimimden faydalanacağıma inanıyorum* & $-0,534$ & & \\
\hline 6. Değişim hakkında korku duyarım & & 0,407 & \\
\hline 7. Değişim konusunda kötü hislerim var & & 0,685 & \\
\hline 8. Değişim ciddi anlamda bana heyecan verir* & & 0,830 & \\
\hline 9. Değişim bana üzüntü verir & & 0,788 & \\
\hline 10. Değişim bana stresli hissettirir & & 0,608 & \\
\hline 11. Yapılan değişimin oluşmasını engellemeye çalışırım & & & 0,871 \\
\hline 12. Yapılan değişime itirazda bulunurum & & & 0,754 \\
\hline $\begin{array}{l}\text { 13. Yapılan değişime ait şikayetlerimi meslektaşlarıma } \\
\text { söylerim }\end{array}$ & & & 0,851 \\
\hline 14. Yapılan değişime ilişkin şikayetlerimi yönetime söylerim & & & 0,868 \\
\hline 15. Yapılan değişikliği başkalarına överim* & & & 0,821 \\
\hline
\end{tabular}

Tablo - 5'te ortaya çıkan faktör analizi neticesinde "Değişime Direnç Ölçeği”nin KMO değerinin 0,840 olduğu saptanmıştır. “Teknostres Ölçeği”nin Barlett değerinin ( $p=0,000$ / $\chi 2=786,579 ; \mathrm{p}<0,01)$ anlamlı olduğu saptanmıştır. Analizde faktör sayısı belirlenirken özdeğerin, 1 'in üzerinde bulunmasına ve faktör yüklerinin de 0,40 ve daha fazla bir değerde bulunması göz önünde bulundurulmuştur. Son olarak elde edilen yapı toplam varyansın \% 66,294'ünü açıkladığı görülmüştür.

Year 4/ 2020, Volume-4, Issue-2 | www.ispecjournal.org 


\subsubsection{Temel Bulgular}

Katılımcıların demografik faktörleri ile teknostres ve değişime direnç ölçeklerine ilişkin ilişkilerinin belirlenmesi amacıyla ' Bağımsız Örneklem T Testi (İndependent T Test) ve Tek Yönlü Varyans Analizi (ANOVA) testleri’’ gerçekleştirilmiştir.

Tablo 6. Teknostres ve değişime direcin yaş etmeni ile arasındaki ilişki

\begin{tabular}{|c|c|c|c|c|c|c|}
\hline & Yaş & $\mathbf{n}$ & $\bar{x}$ & S.S. & $\mathbf{F}$ & $\mathbf{p}$ \\
\hline \multirow{3}{*}{ Teknostres } & $21-30$ & 40 & 2,2077 & 0,40412 & \multirow{3}{*}{1,471} & \multirow{3}{*}{0,235} \\
\hline & $31-40$ & 36 & 2,0855 & 0,32102 & & \\
\hline & 41 ve üstü & 14 & 2,0495 & 0,38356 & & \\
\hline \multirow{3}{*}{$\begin{array}{l}\text { Değişime } \\
\text { Direnç }\end{array}$} & $21-30$ & 40 & 2,0533 & 0,42999 & \multirow{3}{*}{1,635} & \multirow{3}{*}{0,201} \\
\hline & $31-40$ & 36 & 1,9444 & 0,41998 & & \\
\hline & 41 ve üstü & 14 & 1,8238 & 0,44346 & & \\
\hline
\end{tabular}

Tablo - 6 incelendiğinde görüldügüü üzere araştırmaya katılan katılımcıların; teknostres ve değişime dirence ait algıların yaş ögesi göz önünde bulundurularak farklılığın istatistiksel hesaplamada anlamlı çıkıp çıkmayacağını ortaya koymak için tek yönlü varyans analizi uygulanmıştır. Analiz neticesinde, teknostres ve değişime dirence dair katılımcıların algıların yaş etmenine göre istatistiksel olarak \%95 güven düzeyinde anlamlı olmadığı ortaya çıkmıştır $(\mathrm{p}>0,05)$.

Tablo 7. Teknostres ve değişime direcin cinsiyet etmeni ile arasındaki ilişki

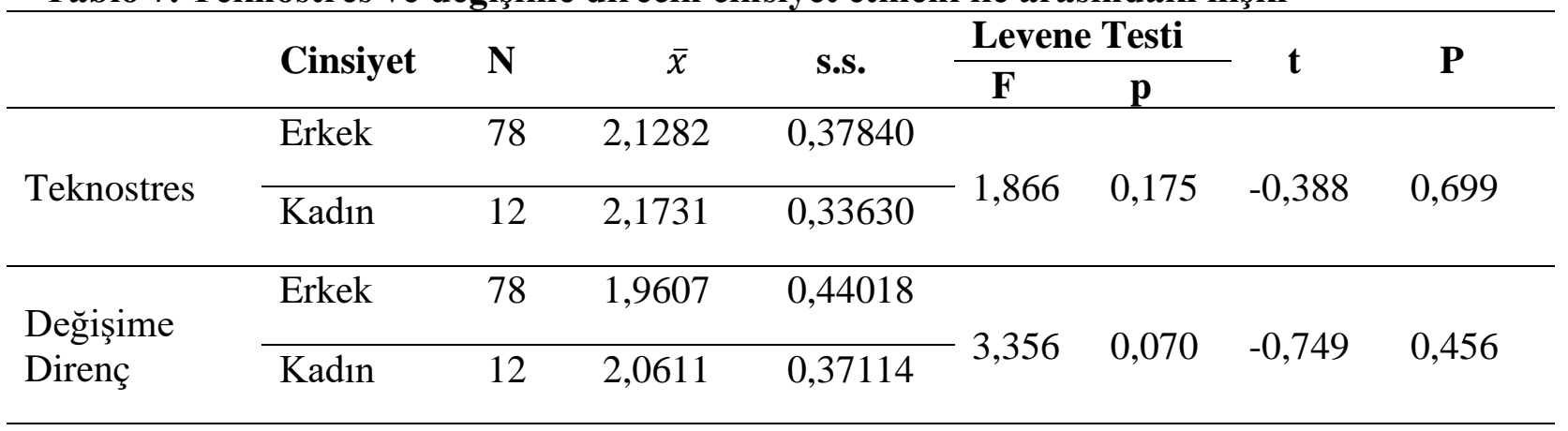

$* \mathrm{P}<0,05$

Tablo - 7 incelendiğinde araştırmaya katılan katılımcıların; teknostres ve değişime dirence ait algıların cinsiyet ögesi göz önünde bulundurularak farklılığın istatistiksel hesaplamada anlamlı çıkıp çıkmayacağını ortaya koymak için bağımsız örneklem t testi uygulanmıştır. Analiz neticesinde, katılımcıların teknostres ve değişime dirence dair katılımcıların cinsiyet 
etmenine göre farklılığ istatistiksel olarak \%95 güven düzeyinde anlamlı olmadığı ortaya çıkmıştır ( $\mathrm{p}>0,05)$.

Tablo 8. Teknostres ve değişime direcin medeni durum etmeni ile arasındaki ilişki

\begin{tabular}{llccccccc}
\hline & Medeni & D & $\bar{x}$ & s.s. & \multicolumn{2}{c}{ Levene Testi } & \multirow{2}{*}{ t } & P \\
\hline \multirow{2}{*}{ Teknostres } & Evli & 66 & 2,0664 & 0,35441 & & $\mathbf{p}$ & & \\
\cline { 2 - 5 } & Bekar & 24 & 2,3205 & 0,36056 & 0,037 & 0,847 & $-2,994$ & $0,004^{*}$ \\
\hline $\begin{array}{l}\text { Değişime } \\
\text { Direnç }\end{array}$ & Evli & 66 & 1,9303 & 0,41319 & & & & \\
\cline { 2 - 5 } & Bekar & 24 & 2,0944 & 0,46476 & 0,266 & 0,607 & $-1,612$ & 0,111
\end{tabular}

$* \mathrm{P}<0,05$

Tablo - 8 incelendiğinde araştırmaya katılan katılımcıların; teknostres ve değiş̧ime dirence ait algıların medeni durum ögesi göz önünde bulundurularak farklılı̆ı̆ı istatistiksel hesaplamada anlamlı çıkıp çıkmayacağını ortaya koymak için bağımsız örneklem $t$ testi uygulanmıştır. Analiz neticesinde, katılımcıların değişime dirence dair katılımcıların algılarının medeni durum etmenine göre farkll1lı̆ ( $\mathrm{p}>0,05)$, fakat teknostres faktör algılarının istatistiksel olarak $\% 95$ güven düzeyinde anlamlı olduğu ortaya çıkmıştır $(\mathrm{t}=-2,994 ; \mathrm{p}<0,05)$. Bekar olanların $(\bar{x}=2,3205)$ teknostres algıları evli olanlara $(\bar{x}=2,0664)$ göre daha yüksektir.

Tablo 9. Teknostres ve değişime direcin eğitim etmeni ile arasındaki ilişki

\begin{tabular}{|c|c|c|c|c|c|c|c|}
\hline & Ĕgitim & $\mathbf{n}$ & $\bar{x}$ & S.S. & $\mathbf{F}$ & $\mathbf{p}$ & Scheffe \\
\hline \multirow{4}{*}{ Teknostres } & Lise & 3 & 2,2051 & 0,16013 & \multirow{4}{*}{1,341} & \multirow{4}{*}{0,266} & \\
\hline & Önlisans & 13 & 2,2781 & 0,48604 & & & \\
\hline & Fakülte & 70 & 2,0934 & 0,35527 & & & \\
\hline & Lisansüstü & 4 & 2,3269 & 0,22094 & & & \\
\hline \multirow{4}{*}{$\begin{array}{l}\text { Değişime } \\
\text { Direnç }\end{array}$} & Lise & 3 & 2,4667 & 0,37118 & \multirow{4}{*}{4,671} & \multirow{4}{*}{$0,005^{*}$} & \multirow{4}{*}{$\begin{array}{c}\text { (önlisans) } \\
\text { (fakülte) }\end{array}$} \\
\hline & Önlisans & 13 & 2,2615 & 0,35949 & & & \\
\hline & Fakülte & 70 & 1,9143 & 0,41504 & & & \\
\hline & Lisansüstü & 4 & 1,7167 & 0,41231 & & & \\
\hline
\end{tabular}

Tablo - 9 incelendiğinde araştırmaya katılan katılımcıların; teknostres ve değişime dirence ait algıların yaş ögesi göz önünde bulundurularak farklılığın istatistiksel hesaplamada anlamlı 
çıkıp çıkmayacağını ortaya koymak için tek yönlü varyans analizi uygulanmıştır. Analiz neticesinde, katılımcıların teknostres faktör algılarının eğitim etmenine göre farklılığ istatistiksel olarak \%95 güven düzeyinde anlamlı olmadığı ( $>>0,05)$, fakat değişime direnç faktör algılarının eğitim etmenine göre farklılığı istatistiksel olarak \%95 güven seviyesinde anlamlı olduğu ortaya çıkmıştır $(\mathrm{F}=4,671 ; \mathrm{p}<0,05)$. Katılımcıların değişime direnç algılarına ait varyansların homojenlik testi sonucunda varyanslar homojen bulunduğundan $(p=0,695$; p >0,05) farklılaşmanın kaynağının belirlenmesi amacıyla post hoc testlerinden Scheffe testi kullanılmıştır. Scheffe testi sonucunda önlisans mezunları ile fakülte mezunları arasında anlamlı bir farklılık ortaya çıkmıştır. Önlisans mezunlarının $(\bar{x}=2,2615)$ değişime direnç algıları fakülte mezunlarına $(\bar{x}=1,9143)$ göre daha yüksektir.

Tablo 10. Teknostres ve değişime direcin kurumda çalışma yılı etmeni ile arasındaki ilișki

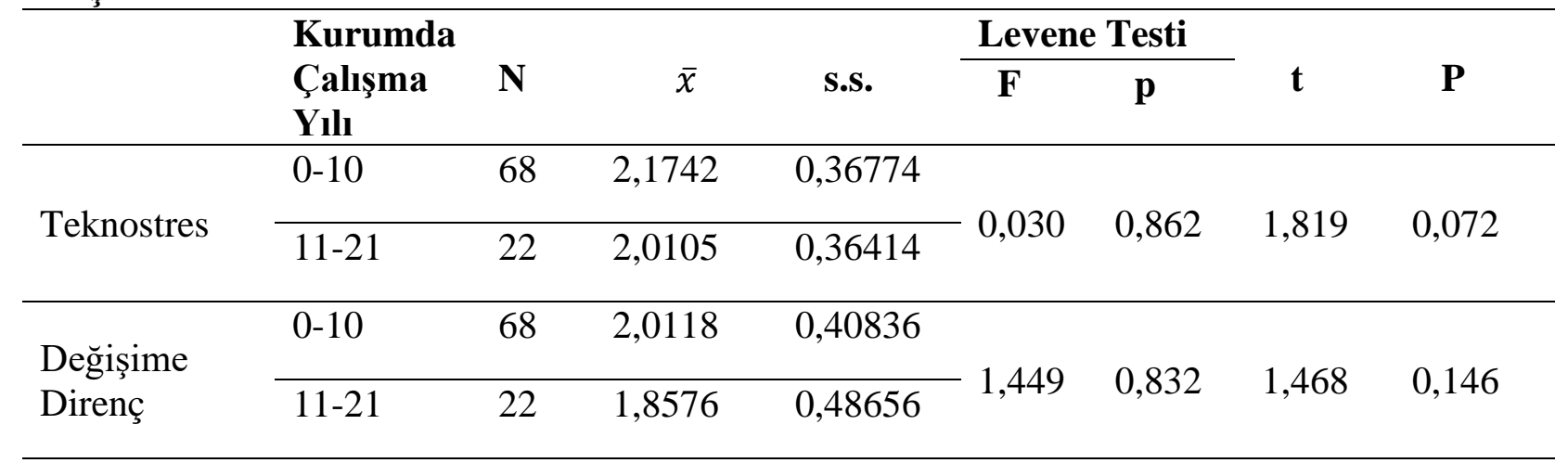

$* \mathrm{P}<0,05$

Tablo - 10 incelendiğinde araştırmaya katılan katılımcıların; teknostres ve değişime dirence ait algıların kurumda çalışma yılı ögesi göz önünde bulundurularak farklılığın istatistiksel hesaplamada anlamlı çıkıp çıkmayacağını ortaya koymak için bağımsız örneklem testi uygulanmıştır. Analiz neticesinde, katılımcıların teknostres ve değişime dirence dair katılımcıların algılarının kurumda çalışma yılı etmenine göre farklılığı istatistiksel olarak \%95 güven düzeyinde anlamlı olmadığı ortaya çıkmıştır ( $p>0,05)$. 
Tablo 11. Teknostres ve değişime direcin meslekte çalışma yılı etmeni ile arasındaki ilişki

\begin{tabular}{|c|c|c|c|c|c|c|c|c|}
\hline & \multirow{2}{*}{$\begin{array}{l}\text { Meslekte } \\
\text { Çalışma } \\
\text { Yılı }\end{array}$} & \multirow[b]{2}{*}{$\mathbf{N}$} & \multirow[b]{2}{*}{$\bar{x}$} & \multirow[b]{2}{*}{ S.S. } & \multicolumn{2}{|c|}{ Levene Testi } & \multirow[b]{2}{*}{$\mathbf{t}$} & \multirow[b]{2}{*}{$\mathbf{P}$} \\
\hline & & & & & $\mathbf{F}$ & $\mathbf{p}$ & & \\
\hline \multirow{2}{*}{ Teknostres } & $0-15$ & 68 & 2,1558 & 0,36394 & \multirow{2}{*}{0,333} & \multirow{2}{*}{0,565} & \multirow{2}{*}{1,488} & \multirow[b]{2}{*}{0,140} \\
\hline & $16-30$ & 22 & 1,9790 & 0,40717 & & & & \\
\hline \multirow{2}{*}{$\begin{array}{l}\text { Değişime } \\
\text { Direnç }\end{array}$} & $0-15$ & 68 & 2,0068 & 0,41860 & \multirow{2}{*}{0,057} & \multirow{2}{*}{0,812} & \multirow[b]{2}{*}{1,958} & \multirow[b]{2}{*}{0,053} \\
\hline & $16-30$ & 22 & 1,7394 & 0,46710 & & & & \\
\hline
\end{tabular}

$* \mathrm{P}<0,05$

Tablo -11 incelendiğinde araştırmaya katılan katılımcıların; teknostres ve değişime dirence ait algıların meslekte çalışma yılı ögesi göz önünde bulundurularak farklılığın istatistiksel hesaplamada anlamlı çıkıp çıkmayacağını ortaya koymak için bağımsız örneklem $t$ testi uygulanmıştır. Analiz neticesinde, katılımcıların teknostres ve değişime dirence dair katılımcıların algılarının meslekte çalışma yılı etmenine göre farklılığı istatistiksel olarak \%95 güven düzeyinde anlamlı olmadığı ortaya çıkmıştır ( $p>0,05)$.

Tablo 12. Teknostres ve değişime direcin kurumdaki pozisyon etmeni ile arasındaki ilişki

\begin{tabular}{|c|c|c|c|c|c|c|}
\hline & $\begin{array}{l}\text { Kurumdaki } \\
\text { Pozisyon }\end{array}$ & $\mathbf{n}$ & $\bar{x}$ & S.S. & $\mathbf{F}$ & $\mathbf{p}$ \\
\hline \multirow{3}{*}{ Teknostres } & Orta Yönetici & 6 & 1,8846 & 0,44256 & \multirow{3}{*}{2,512} & \multirow{3}{*}{0,087} \\
\hline & Alt Yönetici & 8 & 2,3269 & 0,43660 & & \\
\hline & Çalışan & 76 & 2,1336 & 0,35225 & & \\
\hline \multirow{3}{*}{$\begin{array}{l}\text { Değişime } \\
\text { Direnç }\end{array}$} & Orta Yönetici & 6 & 1,5778 & 0,32569 & \multirow{3}{*}{3,345} & \multirow{3}{*}{$0,040^{*}$} \\
\hline & Alt Yönetici & 8 & 2,1417 & 0,54910 & & \\
\hline & Çalışan & 76 & 1,9877 & 0,41178 & & \\
\hline
\end{tabular}

Tablo - 12 incelendiğinde araştırmaya katılan katılımcıların; teknostres ve değişime dirence ait algıların kurumdaki pozisyon ögesi göz önünde bulundurularak farklılığın istatistiksel hesaplamada anlamlı çıkıp çıkmayacağını ortaya koymak için tek yönlü varyans analizi gerçekleştirilmiştir. Analiz neticesinde, teknostrese ait algıların kurumdaki pozisyon etmenine göre istatistiksel olarak \%95 güven düzeyinde anlamlı olmadığı belirlenmiştir $(\mathrm{p}>0,05)$. Fakat değişime direnç faktör algılarının kurumdaki pozisyon etmenine göre farklılığı istatistiksel olarak \%95 güven seviyesinde anlamlı olduğu ortaya çıkmıştır ( $F=3,345$; $\mathrm{p}<0,05)$. Katılımcıların değişime direnç algılarına ait varyansların homojenlik testi sonucunda Year 4/ 2020, Volume-4, Issue-2 | www.ispecjournal.org 
varyanslar homojen bulunduğundan $(\mathrm{p}=0,245 ; \mathrm{p}>0,05)$ farklılaşmanın kaynağının belirlenmesi amacıyla post hoc testlerinden Scheffe testi kullanılmıştır. Scheffe testi sonucunda alt düzey yöneticiler ile orta düzey yöneticiler arasında anlamlı bir farklılık ortaya çıkmıştır. Alt düzey yöneticilerin $(\bar{x}=2,1417)$ değişime direnç algıları orta düzey yöneticilere $(\bar{x}=1,5778)$ göre daha yüksektir.

\subsubsection{Teknostres İle Değişime Direnç Arasındaki İlişkinin Belirlenmesine Yönelik Bulgular}

Çalışmanın bu kısmında teknostres ve değişime direnç toplam skorları ile her ikisinin de alt boyutları arasındaki ilişkiyi saptamak amacıyla uygulanan korelasyon analizi neticelerine ilişkin bulgular ortaya konmuştur. İki değişken arasındaki ilişkiyi açıklamak amacıyla kullanılan korelasyon analiz tekniğinin katsayıları pozitif mükemmel ilişki +1.00 ile negatif mükemmel ilişki -1.00 değerleri arasında yer almaktadır. 0.70 - 1.00 arası için yüksek düzey, $0.30-0.70$ arası için orta düzey, $0.00-0.30$ arası için ise düşük düzey bir ilişkiyi ifade etmektedir. (Büyüköztürk, 2013). Tablo - 13'de Teknostres algısı ile değişime direnç algısı arasındaki ilişkinin saptanması amacıyla uygulanan korelasyon analizi yer almaktadır.

Tablo 13. Teknostres ile değişime direnç arasındaki korelasyon analizi sonuçları

\begin{tabular}{|c|c|c|c|c|c|c|c|c|c|}
\hline & & $\begin{array}{l}\text { TEKNO } \\
\text { STRES }\end{array}$ & $\begin{array}{l}\text { Teknolojik } \\
\text { Yüklenme }\end{array}$ & $\begin{array}{r}\text { Teknolojik } \\
\text { Belirsizlik } \\
\end{array}$ & $\begin{array}{l}\text { Teknolojik } \\
\text { Karmașiklık }\end{array}$ & $\begin{array}{c}\text { DEĞISŞiME } \\
\text { DíRENÇ }\end{array}$ & $\begin{array}{l}\text { Bilişsel } \\
\text { Direnç }\end{array}$ & $\begin{array}{c}\text { Duygusal } \\
\text { Direnç }\end{array}$ & $\begin{array}{c}\text { Davranııssal } \\
\text { Direnç }\end{array}$ \\
\hline $\begin{array}{l}\text { TEKNO } \\
\text { STRES }\end{array}$ & $\mathrm{r}$ & 1 & & & & & & & \\
\hline $\begin{array}{l}\text { Teknolojik } \\
\text { Yüklenme }\end{array}$ & $\mathrm{r}$ & $0,833^{* *}$ & 1 & & & & & & \\
\hline $\begin{array}{l}\text { Teknolojik } \\
\text { Belirsizlik }\end{array}$ & $\mathrm{r}$ & $0,670^{* *}$ & $0,266^{*}$ & 1 & & & & & \\
\hline $\begin{array}{l}\text { Teknolojik } \\
\text { Karmaşıklık }\end{array}$ & $\mathrm{r}$ & $0,720^{* *}$ & $0,454^{* *}$ & $0,286^{* *}$ & 1 & & & & \\
\hline $\begin{array}{l}\text { DEĞİŞíME } \\
\text { DİRENÇ }\end{array}$ & $\mathrm{r}$ & $0,495^{* *}$ & $0,381^{* *}$ & $0,416^{* *}$ & $0,303^{* *}$ & 1 & & & \\
\hline $\begin{array}{l}\text { Bilişsel } \\
\text { Direnç }\end{array}$ & $\mathrm{r}$ & $0,398^{* *}$ & $0,292^{* *}$ & $0,315^{* *}$ & $0,292^{* *}$ & $0,814^{* *}$ & 1 & & \\
\hline $\begin{array}{l}\text { Duygusal } \\
\text { Direnç }\end{array}$ & $\mathrm{r}$ & $0,336^{* *}$ & $0,233^{*}$ & $0,326^{* *}$ & 0,195 & $0,728^{* *}$ & $0,439^{* *}$ & 1 & \\
\hline $\begin{array}{l}\text { Davranışsal } \\
\text { Direnç }\end{array}$ & $\mathrm{r}$ & $0,436^{* *}$ & $0,367^{* *}$ & $0,350^{* *}$ & $0,236^{*}$ & $0,836^{* *}$ & $0,520^{* *}$ & $0,382^{* *}$ & 1 \\
\hline
\end{tabular}

**. Korelasyon 0.01 düzeyinde anlamlıdır (2 - uçlu).

*. Korelasyon 0.05 düzeyinde anlamlıdır $(2$ - uçlu $)$.

Year 4/ 2020, Volume-4, Issue-2 | wWw.ispecjournal.org 
Tablo 13'te görüldüğü üzere korelasyon analizi neticesinde, teknostres ile değişime direnç arasında pozitif yönlü $(r=0,495)$ istatistiksel açıdan anlamlı bir ilişkinin meydana geldiği saptanmıştır $(p<0,01)$. Analiz neticesinde, teknostres ile değişime direnç arasında istatistiki olarak anlamlı bir ilişki vardır olarak belirlenen H1 hipotezini doğruladığını söylemek mümkündür.

Korelasyon analiz tekniği ile teknostres ile değişime direnç alt boyutları arasındaki ilişki tetkik edilmiştir. Teknostresin alt boyutlarının oluşturduğu teknolojik yüklenme, teknolojik belirsizlik ve teknolojik karmaşıklık ile değişime direnç arasındaki ilişki tetkik edildiğinde değişime direncin, teknolojik karmaş1klık $(\mathrm{r}=0,303)$, teknolojik yüklenme $(\mathrm{r}=0,381)$ ve teknolojik belirsizlik $(r=0,416)$ ile pozitif anlamlı bir ilişki içinde olduğu sonucu elde edilmiştir $(p<0,01)$. Analiz neticesinde, teknostres ile değişime direncin alt boyutları arasında istatistiki olarak anlamlı bir ilişki vardır olarak belirlenen H2 hipotezini doğruladığını söylemek mümkündür.

Korelasyon analiz tekniği ile değişime direnç ile teknostres alt boyutları arasındaki ilişki tetkik edilmiştir. Değişime direncin alt boyutlarının oluşturduğu bilişsel direnç, duygusal direnç ve davranışsal direnç ile teknostresin arasındaki ilişki tetkik edildiğinde, teknostresin, bilişsel direnç $(\mathrm{r}=0,398)$, duygusal direnç $(\mathrm{r}=0,336)$ ve davranışsal direnç $(\mathrm{r}=0,436)$ ile de pozitif anlamlı bir ilişki içinde olduğu sonucu elde edilmiştir $(\mathrm{p}<0,01)$. Analiz neticesinde, değişime direnç ile teknostresin alt boyutları arasında istatistiki olarak anlamlı bir ilişki vardır olarak belirlenen H3 hipotezini doğruladığını söylemek mümkündür.

\section{Sonuç}

Çağımızda teknoloji hızlı bir biçimde gelişme göstermekte ve dünya genelinde bu gelişime paralel bir değişim yaşanmaktadır. Organizasyonlar bu gelişmeler karşısında rekabet avantajı elde etme hususunda bilhassa bilgi teknolojilerine ve personel eğitim ve yönetimi açısından önem teşkil eden insan kaynakları departmanları gibi değişimi yönetebileceği alanlara büyük yatırımlar yapmaktadır. Meydana gelen hızlı değişimler nedeniyle teknolojik gelişmelere ayak uydurmak zorunda olan işletmelerde çalışan insanlar yoğun bir strese maruz kalabilmektedir. Çalışanlar üzerinde oluşan bu teknostres ise özellikle çalışanların değişime karşı bir direnç göstermesine neden olabilmektedir. Bu çerçevede, çalışanlar tarafından hissedilen teknostres algısının değişim direnç ile ilişkisinin incelenmesi amacıyla yapılmış hem Türkçe hem 
yabancı kaynaklarda az sayıda çalışmanın var olmasından hareketle, ilgili literatüre katkıda bulunmak ve sonraki çalışmalara ışık tutabilmesi için önem arz eden bu çalışmada, teknostres ile değişime direnç arasında anlamlı bir ilişkinin var olduğu şeklindeki H1 hipotezinin kabul edildiği ortaya konmuştur. Bu doğrultuda saptanan neticelerin daha önce ilgili alanda (Tarafdar vd., 2005; 2007; 2008; Tennakoon ve Syed, 2011; Hung, Chen ve Lin, 2015; Park ve Cho, 2016; Alam, 2016; Olasanmi, 2016; Türen, Erdem ve Kalkın, 2015; Yener, 2018; Özbozkurt, 2019) yapılan araştırmalar ile benzerlik gösterdiği sonucuna vatılmıştır. Buradan hareketle, çalışanların iş hayatına uyum sağlama hususunda üst seviye teknolojiden çekinmesi ve bu teknolojiye uyum gösterememesi şeklinde ortaya çıkan olumsuzluklar, çalışanlarda teknostrese şeklinde ortaya çıkmakta ve bu da onları olumsuz şekilde etkilenerek, değişime karşı bir direnç göstermesine sebebiyet verdiği düşünülmektedir. Öte yandan, teknostres ile değişime direncin alt boyutları arasında istatistiksel olarak anlamlı bir ilişkinin var olduğu ve $\mathrm{H} 2$ hipotezinin kabul edildiği; değişime direnç ile teknostresin alt boyutları arasında da istatistiksel olarak anlamlı bir ilişkinin var olduğu ve H3 hipotezinin kabul edildiği tespit edilmiştir. Bunların yanı sıra, demografik faktörler incelendiğinde, teknostresin medeni durum etmeni ile arasında pozitif yönde anlamlı bir ilişkinin ortaya çıktığı; ancak, değişime direncin medeni durum etmeni ile anlamlı bir ilişkisinin bulunmadığı tespit edilmiştir. Değişime direncin ise eğitim etmeni ve kurumdaki pozisyon ile istatistiksel olarak anlamlı bir ilişkisinin var olduğu; ancak teknostresin eğitim etmeni ve kurumdaki pozisyon ile anlamlı bir ilişkisinin var olmadığı saptanmıştır. Ayrıca, teknostres ve değişime direnç ile yaş, cinsiyet, kurumda çalışma yılı ve meslekte çalışma yılı etmenleri arasında istatistikî olarak anlamlı bir ilişkinin var olmadığı neticesi elde edilmiştir.

Bunların neticesinde, teknostres kavramı teknolojik değişimler ve gelişmeler nedeniyle şuan olduğu gibi gelecekte de organizasyonlar için önemli bir yere ve öneme sahip olacağı düşünülmektedir. Önemi giderek şiddetlenerek artan bu teknolojik değişimlere uyum sağlanması ve meydana gelen stresin azaltılması için ise organizasyonların teknostresi ve değişimi başarılı bir şekilde yönetebilmesi oldukça önem arz edecektir. Bu alanda yetersiz araştırmanın bulunmasından dolayı, yapılacak araştırmaların da bu hususta katkı sağlayacağı düşünülmektedir. 


\section{Kaynakça}

Abramson, L. Y., Metalsky, G. I., \& Alloy, L. B. (1989). Hopelessness depression: A theorybased subtype of depression. Psychological review, 96(2), 358-372.

Agocs, C. (1997). Institutionalized resistance to organizational change: Denial, inaction and repression. Journal of Business Ethics, 16(9), 917-931.

Alam, M. A. (2016). Techno-stress and productivity: Survey evidence from the aviation industry. Journal of Air Transport Management, 50, 62-70.

Arnetz, B. B., \& Wiholm, C. (1997). Technological stress: Psychophysiological symptoms in modern offices. Journal of psychosomatic research, 43(1), 35-42.

Arslan, M. (2001). Örgüt Kültürü, (Ed. Salih Güney), Yönetim ve Organizasyon İçinde. Ankara: Nobel Yayınları.

Basım, H. N., Sözen, H. C., Yeloğlu, H. O., Sağsan, M., Şeşen, H., \& Çetin, F. (2009). Örgütlerde değişim ve ögrenme. Ankara: Siyasal Kitabevi.

Brod, C. (1984). Technostress: The human cost of the computer revolution. Boston: Addison Wesley Publishing Company.

Cam, E. (2004). Çalışma yaşamında stres ve kamu kesiminde kadın çalışanlar. Journal of Human Sciences, 1(1), 1-10.

Cartwright, S., \& Cooper, C. L. (1997). Managing workplace stress (Vol. 1). New York: Sage Publications.

Choi, M., \& Ruona, W. E. (2011). Individual readiness for organizational change and its implications for human resource and organization development. Human Resource Development Review, 10(1), 46-73.

Chung, S. H., Su, Y. F., \& Su, S. W. (2012). The impact of cognitive flexibility on resistance to organizational change. Social Behavior and Personality: an international journal, 40(5), 735-745.

Clark, K., \& Kalin, S. (1996). Technostressed Out? How to Cope in the Digital Age. Library Journal, 121(13), 30-32.

Coetsee, L. (1999). From resistance to commitment. Public Administration Quarterly, 204222.

Daft, R. L. (1999). Leadership: Theory and practice. Harcourt College Publications.

Dent, E. B., \& Goldberg, S. G. (1999). Challenging "resistance to change". The Journal of applied behavioral science, 35(1), 25-41. 
Durna, U. (2002). Yenilik Yönetimi. Ankara: Nobel Yayınları.

Eren, E. (2004). Örgütsel davranış ve yönetim psikolojisi, 7. Baskı, İstanbul: Beta Yayınları, Henry, P. K. (1997). Overcoming Resistance To Organizational Change. Journal Of The American Dietetic Association, 97(10), 145-147.

Hudiburg, R. A. (1989). Psychology of computer use: XVII. The Computer Technology Hassles Scale: Revision, reliability, and some correlates. Psychological Reports, 65(3_suppl2), 1387-1394.

Jena, R. K. (2015). Technostress in ICT enabled collaborative learning environment: An empirical study among Indian academician. Computers in Human Behavior, 51, 1116-1123.

Lazarus, R. S. (1966). Psychological stress and the coping process. New York: Mcgraw-Hill.

Lazarus, R. S., Aldwin, C., \& Coyne, J. C. (1981). Depression and coping in stressful episodes. Journal of abnormal psychology, 90(5), 439-447.

Lewin, K. (1947). Frontiers İn Group Dynamics: Concept, Method and Reality İn Social Science; Social Equilibria and Social Change, Human Relations, 1, 5-41.

Maurer, R. (1996). Using resistance to build support for change. The Journal for Quality and Participation, 19(3), 56-63.

Miller, V. D., Johnson, J. R., \& Grau, J. (1994). Antecedents to willingness to participate in a planned organizational change. Journal Of Applied Communication Research, 22, 59-80.

Mullıns, L. (1993). Management and Organizational Behavior. London: Pitman Publishing.

Oreg, S. (2003). Resistance to change: Developing an individual differences measure. Journal of applied psychology, 88(4), 680-693.

Oreg, S. (2006). Personality, context, and resistance to organizational change. European journal of work and organizational psychology, 15(1), 73-101.

Özbozkurt, O. B. (2019). Teknostres ve Verimlilik Arasındaki İlişkinin İncelenmesi Üzerine Bir Araştırma. Geleceğin Dünyasında Bilimsel ve Mesleki Çalışmalar - Sosyal ve Beşeri Bilimler. Bursa: Ekin Yayınevi.

ÖZGEN, H., \& ÖLÇER, F. (1997). İşletmelerde Örgütsel Değişime Direnme ve Bu Sorunun Çözümlenmesi Üzerine Bir Araştırma. IV. Ulusal Yönetim ve Organizasyon Kongresi, 29, 31.

Özkalp, E., \& Kırel, Ç. (2010). Örgütsel Davranış (4. Baskı). Bursa: Ekin Basım Yayın Dağıtım.

Pehlivan, İ. (1995), Yönetimde Stres Kaynakları. Ankara: Personel Geliştirme Merkezi Yayınları. 
Piderit, K. (1999). Navigating relationships with coworkers: Understanding employees' attitudes toward an organizational change (Doctoral dissertation).

Piderit, S. K. (2000). Rethinking resistance and recognizing ambivalence: A multidimensional view of attitudes toward an organizational change. Academy of management review, 25(4), 783-794.

Porras, J. I., \& Robertson, P. J. (1992). Organizational development: Theory, practice, and research. Consulting Psychologists Press. Palo Alto: CA: Consulting Psychologists Press.

Ragu-Nathan, T. S., Tarafdar, M., Ragu-Nathan, B. S., \& Tu, Q. (2008). The consequences of technostress for end users in organizations: Conceptual development and empirical validation. Information systems research, 19(4), 417-433.

Sabuncuoğlu, Z., \& Tüz, M. (1998). Örgütsel Psikoloji.(3. Bask1). Bursa: Alfa Aktuiel Yayınlar1.

Sabuncuoğlu, Z. (2000). İnsan Kaynakları Yönetimi. Bursa: Ezgi Kitabevi Yayınları.

Sabuncuoğlu E. T. (2008). Liderlik, Değişim ve Yenilik. (Ed. Celalettin Serinkan), Liderlik ve Motivasyon içinde. Ankara: Nobel Yayınları.

Salanova, M., Llorens, S., \& Cifre, E. (2013). The dark side of technologies: Technostress among users of information and communication technologies. International journal of psychology, 48(3), 422-436.

Schuldt, B. A. \& Totten, J. W. (2008). Technological Factors and Business Faculty. Proceedings of the Academy of Information and management sciences, 12(1): 13-19.

Seiye, H. (1997) Stres Without Distress. London: Teach Yourself Books.

Singh, K., Saeed, M., \& Bertsch, A. (2012). Key factors influencing employee response toward change: a test in the telecom industry in India. Journal of management Policy and Practice, 13(3), 66-81.

Stensaker, I. G. \& Meyer, C. B. (2012). Change experience and employee reactions: Developing capabilities for change. Personnel Review, 41(1): 106-124.

Stoner, J. A. F. \& Wankel, C. (1986). Management, Third Edition, Prentice Hall International Edition, New Jersey: Printed in the United States of America

Tarafdar, M., Tu, Q., Ragu-Nathan, B. S., \& Ragu-Nathan, T. S. (2007). The impact of technostress on role stress and productivity. Journal of management information systems, 24(1), 301-328.

Taşlıyan, M. \& Karayılan, D. (2011). Organizasyonlarda Değişim ve Yönetimi, (Ed. İsmail Bakan), Çağdaş Yönetim Yaklaşımları İçinde. 2. Baskı. İstanbul: Beta Yayınları.

Year 4/ 2020, Volume-4, Issue-2 | wWw.ispecjournal.org 
Tınar, M. Y. (1996), Çalışma Psikolojisi. İzmir: Necdet Bükey A.Ş

Wang, K., Shu, Q., \& Tu, Q. (2008). Technostress under different organizational environments: An empirical investigation. Computers in Human Behavior, 24(6), 3002-3013.

Türen, U., Erdem, H., \& KALKIN, G. (2015). İş Yerinde Tekno-Stres Ölçeği: Havacılık ve Bankacılık Sektöründe Bir Araştırma. Çalışma İlişkileri Dergisi, 6(1), 1-19.

Van Dam, K., Oreg, S., \& Schyns, B. (2008). Daily work contexts and resistance to organisational change: The role of leader-member exchange, development climate, and change process characteristics. Applied psychology, 57(2), 313-334.

Waddell, D., \& Sohal, A. S. (1998). Resistance: a constructive tool for change management. Management decision. 36(8), 543-548.

Weil, M. M., \& Rosen, L. D. (1999). Don't Let Technology Enslave You. Workforce, 78(2), 56-58.

Wolever, R. Q., Bobinet, K. J., McCabe, K., Mackenzie, E. R., Fekete, E., Kusnick, C. A., \& Baime, M. (2012). Effective and viable mind-body stress reduction in the workplace: a randomized controlled trial. Journal of occupational health psychology, 17(2), 246.

YENER, Ü. S. (2018). Teknostresin İş Performansı Üzerindeki Etkisi; Tükenmişliğin Arac1 Rolü. Afyon Kocatepe University Journal of Social Sciences, 20(2) 85-101. 